\title{
Beş Yıldızlı Otel Sağlıklı Yaşam Merkezlerinin, Hizmet Kalitesi ve Fiyatlarının Üyelerin Üyelik Yenileme Eğilimlerindeki Rolï
}

\author{
The Effects of Service Quality and Price of the Health Clubs in \\ Five Star Hotels upon the Membership Retention Tendency
}

\author{
Barış ANLATICI* \\ Turgay BICÇER ${ }^{* * *}$
}

\begin{abstract}
Öz
Çalışmanın amacı, İstanbul Anadolu yakasında bulunan beş yıldızlı otel sağlıklı yaşam merkezlerine yönelik hizmet kalitesi, beklenti ve algının kulüp üyelerinin üyeliği yenileme kararları üzerine etkilerinin incelenmesidir. Bu araştırma ile sağlıklı yaşam merkezlerinin üyelerini ellerinde tutmak için ne şekilde bir hizmet anlayışı ile nasıl bir fiyatlandırma politikası uygulamaları gerekliliği hususunda model oluşturulmaya çalışılacaktır. Buradan elde edilecek sonuçlarla, ticari amaçla kurulmuş olan beş yıldız otel sağlıklı yaşam merkezleri stratejik pazarlama kararlarını somut verilere dayandırarak verebileceklerdir. Araştırma kapsamında nicel analiz yöntemi tercih edilmiştir. Katılımcıların \%52,4’ü (162) aldıkları hizmetten hiç memnun değilken, \%35,9’u (111) memnun değil, \%8,4’ü (26) kararsı, \%1,6’sı (5) memnun ve \%1,6’sı (5) son derece memnundur. Katılımcıların \%55,7’si (172) aldıkları hizmete karşılık ödedikleri ücretten düşük düzeyde memnun iken, \%38,5’i (119) kararsız, \%5,8’i (18) ise yüksek düzeyde memnundur. Katılımcıların \%92,2'si (285) tekrar üye olmayı düşünürken, yalnızca \%7,8’i (24) tekrar üye olmayı düşünmemektedir. Yapılan analizler neticesinde aldıkları hizmetten memnun ve son derece memnun olan katılımcıların diğer katılımcılara göre üyelik yenileme konusunda daha olumlu oldukları görülmektedir. Ayrıca 18 yaş altı ve 50 yaş üstü katılımcıların diğer katılımcılara göre beklentilerinin daha düşük olduğu görülmektedir. Diğer demografik özelliklere göre istatistiksel olarak anlamlı bir farklılık tespit edilmemiştir.
\end{abstract}

Anahtar Kelimeler: üyelik yenileme, hizmet, sağlıklı yaşam merkezi, kalite, fiyat.

\footnotetext{
* $\quad$ Bu çalışma, "Beş Yıldızlı Otel Sağlıklı Yaşam Merkezlerinin, Hizmet Kalitesi ve Fiyatlarının Üyelerin Üyelik Yenileme Eğilimlerindeki Rolü Üzerine Bir İnceleme” isimli tez çalışmasından türetilmiştir. Marmara Üniversitesi, Sağlık Bilimleri Enstitüsü, 2019.

** Yüksek Lisans, Marmara Üniversitesi, Sağlık Bilimleri Enstitüsü, banlatici@gmail.com

*** Prof. Dr. Turgay Biçer, Marmara Üniversitesi, Spor Bilimleri Fakültesi, turgay@marmara.edu.tr
}

Geliş tarihi: 21.03.2019, Kabul tarihi: 30.05.2019 


\begin{abstract}
In the study, it is aimed to investigate the effects of service quality and price of the health clubs in five star hotels in Anatolia Side of Istanbul upon the membership retention decisions of the members. For this purpose, it is tried to set a model of service quality and pricing strategy in order to keep the retention at the desired levels. The commercial fitness centers of the five star hotels will be planning their strategical marketing decision based on concrete datas gained through this study. Quantitive analyses method has been used for the research. Out of 309 participants, 52,4\% (162) of them were totally dissatisfied, 35,9\% (111) of them were dissatisfied, 8,4\% (26) of them were unstable, 1,6\% (5) of them were satisfied and 1,6\% (5) of them were reasonably satisfied about the quality of the services they receive. About the price and quality comparison; $55,7 \%$ (172) of the participants have low satisfaction level about the price they have paid for the services they receive. $38,5 \%$ (119) of them were unstable and 5,8\% (18) were reasonably satisfied. While $92,2 \%$ (285) of the participants were in the tendency of retention, only 7,8\% (24) of them haven't got the tendency of retention. It is deducted through the analizes that the satisfied and reasonably satisfied participants about the quality of the services have more tendency for retention. Besides, the participants below 18 and above 50 of age were found less demanding according to the other age groups. There has no other significant differences been found according to the demographical informations.
\end{abstract}

Keywords: retention, service, health club, quality, price.

\title{
GiRiş
}

İstanbul Anadolu Yakası̉ndaki beş yıldızlı otellerin Sağlıklı Yaşam ve Sudan Gelen Sağlık (Sanus Per Aquam) (SPA) merkezleri arasında her geçen gün artan bir rekabet gözlemlenmektedir.

Oteller, asıl fonksiyonları müşterilerin dinlenme ve geceleme ihtiyaçlarına yönelik hizmetler sağlamak olan, bununla beraber, yiyecek, içecek, eğlence ve spor ihtiyaçları için de ek birimleri bulundurabilen tesislerdir. Oteller; bir, iki, üç, dört, beş yıldızlı oteller olarak sinıflandırılırlar. Beş yıldızlı oteller; yerleşme durumu, yapı, tesisat, donatım, dekorasyon ve hizmet standardı olarak üstün özellikler gösteren, dört yıldızlı oteller için aranılan şartlarla ek nitelikleri taşıyan en az yüz yirmi odalı otellerdir. Beş yıldızlı otellerin sağlıklı yaşam ve SPA ile ilgili olarak en az aşağıdaki imkanlardan üç adedini sağlamaları gerekmektedir (T.C. Resmi Gazete 21 Haziran 2005, sayı: 8948):

- Kapalı yüzme havuzu

- Açık yüzme havuzu

- Kırk metrekare ve üzerinde aletli jimnastik salonu

- Aerobik egzersiz veya bilardo salonu

- Alarm sistemli sauna

- Türk hamamı

- Mini golf

- Tenis veya voleybol sahasi

- Trambolin, bowling salonu

- Go-kart pisti, kayak ve deniz sporları

- Squash salonu veya benzeri imkanlar 
Müşteri sadakati kavramı üyelik yenileme, yani tekrar satın alma olgusunu da kapsar. Bu; şirketin karlılık ve başarısı için anahtar rol oynar (Ganesh ve ark., 2000). Bugünün rekabetçi koşullarında eski müşteriyi elde tutmak bir organizasyonu başarıya ulaştırmak için hayati öneme sahiptir (Ferrand ve ark., 2010).

Hizmet sadakati, müşterilerin önceki deneyimleri ve gelecek beklentilerine yönelik olarak tekrar satın alma eğilimidir. Somut ürünlerin aksine, hizmet sadakati; hizmet pazarlamasının kavramlarından kişisel ilişkilere bağlıdır (Çankaya ve Çilingir, 2008).

Parasuraman (1985) ve arkadaşlarına göre hizmet kalitesi ile rekabetçi sektörlerdeki organizasyonların başarısı arasında pozitif yönde anlamlı bir bağ bulunmaktadır. Howat (1996) ve arkadaşlarına göre de servis kalitesi arttıkça müşteri tatmini, sadakat ve ağızdan ağıza reklam artar, böylece organizasyon daha da başarılı duruma gelir (aktaran Yıldız, 2011). Çankaya ve Çilingir (2008)'e göre hizmet işletmesinin sadık müşterisi olmadan önce hizmetin maliyetine karşlık faydaları belirli bir ölçü birimi ile değerlendirip sıralanmak suretiyle fayda-maliyet analizi yapılır. Türkiye’de spor ile kalite kavramını ilk defa bir araya getirmiş olan Biçer (2008) 'e göre kalite birçok farklı biçimde tanımlanabilir ancak önemli olan kaliteye ulaşmaktır ve Toplam Kalite Yönetimi başta futbol olmak üzere sporla ilgili birçok alanda kullanılabilir.

Tek bir müşterinin bile sürekli müşseri olarak tutulabilmesi ve tabi hale gelmesi rekabetin yüksek olduğu ekonomilerde işletmeler için hayati rol oynar. Bu bakımdan fiyat aynı zamanda müşteri bağlılığı yaratma aracı olarak da kullanılmaktadır (Gülbuçuk, 2008). Fiyat algısının tüketicinin satın alma kararı üzerinde anlamlı bir etkisi vardır. Bu algı kişiden kişiye değişiklik gösterir. Yüksek fiyat bazen tüketicinin satın alma kararında olumsuz etki yaratabilir, bazen de yüksek fiyat müşteri için kalite göstergesidir (Raza ve Rehman, 2012).

Araştırma kapsamında beş yıldızlı otel sağlıklı yaşam merkezlerinin sunmuş oldukları hizmet kalitesi ve fiyatın yanı sıra üyelerin beklenti ve algılarının üyelikleri yenileme üzerindeki etkilerini incelemek amaçlanmıştır. Böylece hem akademik anlamda literatürde az sayıda bulunan çalışmaya katkı sağlamak hem de sektörde bulunan profesyonel yöneticilere bir yol haritası ve kılavuz oluşturmak hedeflenmiştir.

\section{YÖNTEM}

\section{Araştırmanın Amacı}

Beş yıldızlı otellerdeki sağlıklı yaşam merkezlerinde fiyat ve hizmet kalitesinin üyelik yenileme üzerine etkileri incelenerek, sektörde ve akademik anlamda daha önce hem fiyat ve hem de hizmet kalitesini tek bir çalışmada ele alması yönü ile benzeri olmayan bir çalışma yapıldı.

Çalı̧̧manın amacı; sektörde faaliyet gösteren profesyonel yöneticilere hizmet kalitesi ve fiyatlandırma ile ilgili model oluşturmak, ileride konu ile ilgili yapılacak olan akademik çalışmalara katkı sağlamaktı. 


\section{Araştırmanın Yöntemi}

İstanbul Anadolu yakasının önde gelen beş yıldızlı otellerinden Wyndham Grand İstanbul Kalamış Marina Hotel ve İstanbul Marriott Hotel Asia Sağlıklı Yaşam Merkezlerinde 1 - 30 Mayıs 2016 tarihleri arasında anket uygulaması yapıldı. Anket sonuçları nicel analiz yöntemleri ile incelendi ve sonuçların değerlendirilmesinde İstatistiksel Analiz Paket Programı (SPSS) kullanıldı.

\section{Araştırmanın Evreni ve Örneklemi}

Araştırmanın evrenini İstanbul'un Anadolu Yakası'nda bulunan beş yıldızlı otel sağlıklı yaşam merkezlerinin üyeleri oluşturmaktadır. Turizm Bakanlığı ve Turistik Otelciler İşletmeciler ve Yatırımcılar Birliği (TUROB) üzerinden yapılan araştırmalarda İstanbul Anadolu yakasında faal olan 5 yıldızlı otellerin kesin sayısına ulaşılamamıştır. Araştırmacının kendi araştırmaları sonucu ulaştığı rakam 19 - 20 arasındadır. Yargısal örnekleme ile bu otellerin sağlıklı yaşam merkezlerine kayıtlı üye sayısının 30.000 civarında olduğu öngörülmüştür. Anketin evreni temsili için Yazıcıoğlu ve Erdoğan’n (2004) Örneklem Büyüklükleri tablosundan yararlanılmıştır ve anket 302 kişiye uygulanmıştır.

Anket, uygun örnekleme yöntemi ile seçilen 16 - 60 yaş aralığındaki Grand İstanbul Kalamış Marina Hotel ve İstanbul Marriott Hotel Asia otelleri merkezi üyelerine uygulanmıştır. Anket çalışması her iki kurumda da araştırmacı tarafından yüz yüze mülakat şeklinde yürütüldü.

\section{Veri Toplama Araçları}

Araştırmada kullanılan veri toplama aracı, sağlık ve sağlıklı yaşam kulüplerinin hizmet kalitesini değerlendirmek amacıyla Lam, Zhang ve Jensen (2005) tarafından geliştirilmiş olan SQAS (Service Quality Assessment Scale ) anketidir. Anketin geçerlik ve güvenirlik çalışması; Türkiye’de Gürbüz, Koçak ve Lam (2005) tarafından yapılmıştır. Hizmet Kalitesi Değerlendirme Ölçeği, 40 madde ve altı boyuttan oluşmaktadır. Bunlar; personel, program, soyunma odası, fiziksel özellikler, antrenman tesisi, çocuk bakımı boyutlarıdır. Ölçek iki formdan oluşmaktadır. İlk form hizmet kalite beklentisini ve ikinci form ise hizmet algısını ölçmeyi amaçlamaktadır. Çalışmada üyelere ait yaş, cinsiyet, eğitim düzeyi, gelir düzeyi gibi demografik bilgiler kişisel bilgi formu ile belirlenmiştir. Ayrıca, demografik sorulara ek olarak tesisten alınan hizmetlerle ilgili memnuniyet derecesini, alınan hizmete göre ücretin değerlendirilmesini ve tekrardan kulübe üye olup olmama düşüncesini değerlendiren sorular da soruldu. Araştırmada kullanılan ölçeklerin Cronbach 's Alpha değerleri Hizmet kalite beklentisi için ,967 ve hizmet algısını için ,957 olarak bulunmuştur. Her iki ölçek içinde yüksek derecede güvenilirdir sonucuna ulaşılmaktadır.

\section{Araştırmanın Sınırlılıkları}

Araştırmanın bir takım sınırlılıkları vardır. Öncelikli sınırlılık zamandır, tüm anketlerin bir ay içerisinde tamamlanması öngörülmüştü. Araştırma 45 günde tamamlandı. Daha uzun zamana 
yayılmış bir uygulamada daha farklı sonuçlara varmak mümkün olabilecekti. Araştırmanın bir diğer sınırllığı ise evrenin tamamına ulaşılamaması idi. İşletmeler işletme politikaları gereği bazı bilgileri saklı tutmaktadır.

\section{Araştırmanın Hipotezleri}

1. Yaşa göre sağlıklı yaşam merkezlerinden beklentilerinde istatistiksel olarak anlamlı bir farklılık var midır?

2. Cinsiyete göre sağlıklı yaşam merkezi üyelerinin sağlıklı yaşam merkezlerinden beklentilerinde istatistiksel olarak anlamlı bir farklılık var mıdır?

3. Medeni duruma göre sağlıklı yaşam merkezi üyelerinin sağlıklı yaşam merkezlerinden beklentilerinde istatistiksel olarak anlamlı bir farklılık var mıdır?

4. Eğitim durumuna göre sağlıklı yaşam merkezi üyelerinin sağlıklı yaşam merkezlerinden beklentilerinde istatistiksel olarak anlamlı bir farklılık var mıdır?

5. Yaşa göre sağ lıklı yaşam merkezi üyelerinin sağlıklı yaşam merkezi hizmet algılarında istatistiksel olarak anlamlı bir farklılık var mıdır?

6. Cinsiyete göre sağlıklı yaşam merkezi üyelerinin sağlıklı yaşam merkezi hizmet algılarında istatistiksel olarak anlamlı bir farklılık var mıdır?

7. Medeni duruma göre sağ lıklı yaşam merkezi üyelerinin sağlıklı yaşam merkezi hizmet algılarında istatistiksel olarak anlamlı bir farklılık var mıdır?

8. Eğitim durumuna göre sağlıklı yaşam merkezi üyelerinin sağlıklı yaşam merkezi hizmet algılarında istatistiksel olarak anlamlı bir farklılık var mıdır?

9. Alınan hizmetten memnuniyet düzeyine göre sağlıklı yaşam merkezi üyelerinin tekrar üyelik düşüncelerinde istatistiksel olarak anlamlı bir farklılık var mıdır?

10. Ödenen ücretten memnuniyet düzeyine göre sağlıklı yaşam merkezi üyelerinin tekrar üyelik düşüncelerinde istatistiksel olarak anlamlı bir farklılık var mıdır?

\section{Veri Analizi}

Grand İstanbul Kalamış Marina Hotel ve İstanbul Marriott Hotel Asia Sağlıklı Yaşam Merkezi üyelerine veri toplama araçları uygulandı ve araştırmanın verileri toplandı. Uygulama hakkında her gruba araştırmacı tarafından gerekli açıklamalar yapıldı. Uygulamanın ardından, ölçme araçları kontrol edilerek ve boş bırakılan, eksik ya da yanlış cevaplandırılan ölçme araçları araştırma kapsamına alınmamıştır.

Analizler sosyal bilimler alanında genel kabul görmüş SPSS istatistik paket programında yapıldı. Değişkenler arasındaki farklılıkları incelemek amacıyla Mann Whitney U ve Kruskal Wallis testlerinden yararlanıldı. 
Tablo 1. Normallik Testi

\begin{tabular}{lllllll}
\hline & \multicolumn{5}{l}{ Kolmogorov-Smirnov ${ }^{\mathrm{a}}$} & \multicolumn{5}{l}{ Shapiro-Wilk } \\
\hline istatistik & $\mathrm{df}$ & Anlamlllk & istatistik & df & Anlamllik \\
\hline Beklenti & 234 & 309 &, 000 &, 731 & 309 &, 000 \\
\hline Alg1 & 200 & 309 &, 000 &, 819 & 309 &, 000 \\
\hline
\end{tabular}

$H_{0}$ : \%95 güven düzeyinde seri normal dağılıma sahiptir.

$H_{A}: \% 95$ güven düzeyinde seri normal dağılıma sahip değildir

Hem Kolmagorov-Smirnov hem de Shapiro-Wilk değerleri incelendiğinde kaynak ve çevre ölçekleri için sig. değeri 0,05'ten küçük olduğundan $H_{0}$ RED, \%95 güven düzeyinde seri normal dağılıma sahip değildir sonucuna varılmaktadır. Bu doğrultuda yapılacak fark analizlerinde parametrik olmayan testler kullanılacaktır.

\section{BULGULAR}

Tablo 2. Katılımcıların Cinsiyet, yaş, Medeni Durum ve Eğitim Durumu Dağılımı

\begin{tabular}{llll}
\hline Özellik & & Frekans & Yüzde \\
\hline Cinsiyet & Erkek & 166 & 53,7 \\
& Kadın & 143 & 46,3 \\
& Toplam & 309 & 100,0 \\
\hline Yaş & $16-17$ & 21 & 6,8 \\
& $18-30$ & 151 & 48,9 \\
& $31-40$ & 88 & 28,5 \\
& $41-50$ & 33 & 10,7 \\
& 50 üzeri & 16 & 5,2 \\
& Toplam & 309 & 100,0 \\
\hline Medeni Durum & Evli & 120 & 38,8 \\
& Bekar & 189 & 61,2 \\
& Toplam & 309 & 100,0 \\
\hline Eğitim Durumu & İlköğretim & 16 & 5,2 \\
& Lise & 117 & 37,9 \\
& Üniversite & 171 & 55,3 \\
& Üniversite Öğrencisi & 2 &, 6 \\
& Lisansüstü & 3 & 1,0 \\
& Toplam & 309 & 100,0 \\
\hline
\end{tabular}

Katılımcıların \%53,7'si (166) erkek, \%46,3’ü (143) kadındır. Katılımcıların yaş dağılımları incelendiğinde \%48,9'unun (151) 18-30 yaş aralığında olduğu görülürken, \%28,5’i (88) 3140, \%10,7’si (33) 41-50, \%6,8’i (21) 12-17 yaş aralığındadır. Katılımcıların \%5,2'si (16) ise 50 yaş üzeridir. Katılımcıların \%61,2'si (189) bekar iken \%38,8'i (120) evlidir. Katılımcıların eğitim durumları incelendiğinde \%55,3'ünün (171) üniversite mezunu, \%37,9’u (117) lise mezunu, \%5,2'si 
(16) ilköğretim mezunu, \%1’i (3) lisansüstü mezunu ve \%0,6’sı (2) üniversite öğrencisi olduğu görülmektedir.

Tablo 3. Katılımcıların Üyelik Süresi, Aldıkları Hizmetten Memnunluk, Aldıkları Hizmete Karşılık Ödedikleri Ücretten Memnuniyet ve Tekrar Üyelik Düşüncesi Dağılımı.

\begin{tabular}{llll}
\hline Özellik & & Frekans & Yüzde \\
\hline Üyelik Süresi Dağılımı & 1 aydan az & 33 & 10,7 \\
& $1-6$ ay arası & 79 & 25,6 \\
& $6-12$ ay arası & 97 & 31,4 \\
& $1-2$ yıl arası & 58 & 18,8 \\
& 2 yıldan fazla & 42 & 13,6 \\
& Toplam & 309 & 100,0 \\
\hline Aldıkları Hizmetten Memnunluk & Hiç Memnun Değilim & 162 & 52,4 \\
& Memnun Değilim & 111 & 35,9 \\
& Kararsızım & 26 & 8,4 \\
& Memnunum & 5 & 1,6 \\
& Son Derece Memnunum & 5 & 1,6 \\
& Toplam & 309 & 100,0 \\
\hline Aldıkları Hizmete Karşıllk Ödedikleri Ücretten Memnuniyet & Düşük & 172 & 55,7 \\
& Kararsızım & 119 & 38,5 \\
& Yüksek & 18 & 5,8 \\
& Toplam & 309 & 100,0 \\
\hline Tekrar Üyelik Düșüncesi & Evet & 285 & 92,2 \\
& Hayır & 24 & 7,8 \\
& Toplam & 309 & 100,0 \\
\hline
\end{tabular}

Katılımcıların \%31,4’ü (97) 6-12 ay arası süredir çalışırken, \%25,6’sı (79) 1-6 ay arası, \%18,8’i (58) 1-2 yıl arası, \%13,6’sı (42) 2 yıldan fazla ve \%10,7'si (33) 1 aydan az süredir üye durumdadırlar. Katılımcıların \%52,4'ü (162) aldıkları hizmetten hiç memnun değilken, \%35,9’u (111) memnun değil, \%8,4’ü (26) kararsız, \%1,6’sı (5) memnun ve \%1,6’s1 (5) son derece memnundur. Katılımcıların \%55,7'si (172) aldıkları hizmete karşılık ödedikleri ücretten düşük düzeyde memnun iken, \%38,5’i (119) kararsız, \%5,8’i (18) ise yüksek düzeyde memnundur. Katılımcıların \%92,2’si (285) tekrar üye olmayı düşünürken, yalnızca \%7,8’i (24) tekrar üye olmayı düşünmemektedir.

Tablo 4. Yaşa Göre Beklenti Ölçeği Fark Analizi

\begin{tabular}{llll}
\hline Özellik & Chi-square & df & Asymp. Sig. \\
\hline Personel Kalitesi & 7,116 & 4 &, 130 \\
\hline Program Kalitesi & 10,407 & 4 &, 034 \\
\hline Soy. Odaları Kalitesi & 13,718 & 4 &, 008 \\
Fiziksel Özellikler Kalitesi & 7,514 & 4 &, 111 \\
Tesis Kalitesi & 2,904 & 4 &, 574 \\
Çocuk Bakım Kalitesi & 4,789 & 4 &, 310 \\
\hline
\end{tabular}


$\boldsymbol{H}_{0}$ : Yaşa göre sağlıklı yaşam merkezi üyelerinin sağlıklı yaşam merkezlerinden beklentilerinde istatistiksel olarak anlamlı bir fark yoktur.

$H_{A}$ : Yaşa göre sağlıklı yaşam merkezi üyelerinin sağlıklı yaşam merkezlerinden beklentilerinde istatistiksel olarak anlamlı bir fark vardır

Normallik testi bulgusu doğrultusunda parametrik olmayan Kruskal Wallis Testi kullanılmıştır. Yapılan sınamada personel kalitesi, fiziksel özellikler kalitesi, antreman tesisi kalitesi ve çocuk bakımı kalitesi alt boyutları için Asymp. Sig. değeri 0,05’ten büyük olduğundan $H_{0}$ REDDEDİLEMEZ, yaşa göre sağlıklı yaşam merkezi üyelerinin sağlıklı yaşam merkezlerinden beklentilerinde istatistiksel olarak anlamlı bir fark yoktur sonucuna varılmaktadır. Program kalitesi ve soyunma odası kalitesi alt boyutları için ise Asymp. Sig. değerleri 0,05’ten küçüktür ve bu sebeple $H_{0}$ RED, yaşa göre sağlıklı yaşam merkezi üyelerinin sağlıklı yaşam merkezlerinden beklentilerinde istatistiksel olarak anlamlı bir fark vardır sonucu elde edilmektedir. Rank değerleri incelendiğinde 18 yaş altı ve 50 yaş üstü katılımcıların diğer katılımcılara göre beklentilerinin daha düşük olduğu görülmektedir.

Tablo 5. Cinsiyete Göre Beklenti Ölçeği Fark Analizi

\begin{tabular}{lllllll} 
& $\begin{array}{l}\text { Personel } \\
\text { Kalitesi }\end{array}$ & $\begin{array}{l}\text { Program } \\
\text { Kalitesi }\end{array}$ & $\begin{array}{l}\text { Soyunma } \\
\text { Odası Kalitesi }\end{array}$ & $\begin{array}{l}\text { Fiziksel } \\
\text { Özellikler } \\
\text { Kalitesi }\end{array}$ & $\begin{array}{l}\text { Antrenman } \\
\text { Tesisi Kalitesi }\end{array}$ & $\begin{array}{l}\text { Çocuk Bakımı } \\
\text { Kalitesi }\end{array}$ \\
\hline Mann-Whitney U & 11745,5 & 11855,0 & 11844,0 & 11562,0 & 11775,0 & 11451,0 \\
Wilcoxon W & 22041,5 & 22151,0 & 22140,0 & 25423,0 & 22071,0 & 21747,0 \\
Z &,- 166 &,- 019 &,- 034 &,- 418 &,- 129 &,- 575 \\
Asymp. Sig. (2-tailed) &, 868 &, 985 &, 972 &, 676 &, 898 &, 565 \\
\hline
\end{tabular}

$H_{0}$ : Cinsiyete göre sağlıklı yaşam merkezi üyelerinin sağlıklı yaşam merkezlerinden beklentilerinde istatistiksel olarak anlamlı bir fark yoktur.

$H_{A}$ : Cinsiyete göre sağlıklı yaşam merkezi üyelerinin sağlıklı yaşam merkezlerinden beklentilerinde istatistiksel olarak anlamlı bir fark vardır.

Normallik testi bulgusu doğrultusunda parametrik olmayan Mann Whitney U Testi kullanılmıştır. Yapılan sınamada Asymp. Sig. değeri tüm alt boyutlar için 0,05’ten büyük olduğundan $H_{0}$ REDDEDİLEMEZ, cinsiyete göre sağlıklı yaşam merkezi üyelerinin sağlıklı yaşam merkezlerinden beklentilerinde istatistiksel olarak anlamlı bir fark yoktur sonucuna varılmaktadir. 
Tablo 6. Medeni Duruma Göre Beklenti Ölçeği Fark Analizi

\begin{tabular}{lllllll} 
& $\begin{array}{l}\text { Personel } \\
\text { Kalitesi }\end{array}$ & $\begin{array}{l}\text { Program } \\
\text { Kalitesi }\end{array}$ & $\begin{array}{l}\text { Soyunma } \\
\text { Odası Kalitesi }\end{array}$ & $\begin{array}{l}\text { Fiziksel } \\
\text { Özellikler } \\
\text { Kalitesi }\end{array}$ & $\begin{array}{l}\text { Antrenman } \\
\text { Tesisi Kalitesi }\end{array}$ & $\begin{array}{l}\text { Çocuk } \\
\text { Bakımı } \\
\text { Kalitesi }\end{array}$ \\
\hline Mann-Whitney U & 10373,0 & 11297,0 & 10654,5 & 11090,0 & 11199,0 & 10996,0 \\
Wilcoxon W & 28328,0 & 29252,0 & 17914,5 & 29045,0 & 18459,0 & 28951,0 \\
Z & $-1,33$ &,- 059 &,- 968 &,- 349 &,- 198 &,- 484 \\
Asymp. Sig. (2-tailed) &, 184 &, 953 &, 333 &, 727 &, 843 &, 628 \\
\hline
\end{tabular}

$H_{0}$ : Medeni duruma göre sağlıklı yaşam merkezi üyelerinin sağlıklı yaşam merkezlerinden beklentilerinde istatistiksel olarak anlamlı bir fark yoktur.

$H_{A}$ : Medeni duruma göre sağlıklı yaşam merkezi üyelerinin sağlıklı yaşam merkezlerinden beklentilerinde istatistiksel olarak anlamlı bir fark vardır.

Normallik testi bulgusu doğrultusunda parametrik olmayan Mann Whitney U Testi kullanılmıştır. Yapılan sinamada Asymp. Sig. değeri tüm alt boyutlar için 0,05’ten büyük olduğundan $H_{0}$ reddedilemez, medeni duruma göre sağlıklı yaşam merkezi üyelerinin sağlıklı yaşam merkezlerinden beklentilerinde istatistiksel olarak anlamlı bir fark yoktur sonucuna varılmaktadır.

Tablo 7. Eğitim Durumuna Göre Beklenti Ölçeği Fark Analizi

\begin{tabular}{lllllll} 
& $\begin{array}{l}\text { Personel } \\
\text { Kalitesi }\end{array}$ & $\begin{array}{l}\text { Program } \\
\text { Kalitesi }\end{array}$ & $\begin{array}{l}\text { Soyunma } \\
\text { Odası Kalitesi }\end{array}$ & $\begin{array}{l}\text { Fiziksel } \\
\text { Özellikler } \\
\text { Kalitesi }\end{array}$ & $\begin{array}{l}\text { Antrenman } \\
\text { Tesisi Kalitesi }\end{array}$ & $\begin{array}{l}\text { Çocuk Bakımı } \\
\text { Kalitesi }\end{array}$ \\
\hline Chi-square & 4,658 & 1,676 & 9,314 & 4,951 & 4,279 & 7,394 \\
Df & 4 & 4 & 4 & 4 & 4 & 4 \\
Asymp. Sig. &, 324 &, 795 &, 054 &, 292 &, 370 &, 116 \\
\hline
\end{tabular}

a. Kruskal Wallis Testi

$H_{0}$ : Eğitim durumuna göre sağlıklı yaşam merkezi üyelerinin sağlıklı yaşam merkezlerinden beklentilerinde istatistiksel olarak anlamlı bir fark yoktur.

$H_{A}$ : Eğitim durumuna göre sağlıklı yaşam merkezi üyelerinin sağlıklı yaşam merkezlerinden beklentilerinde istatistiksel olarak anlamlı bir fark vardır.

Normallik testi bulgusu doğrultusunda parametrik olmayan Kruskal Wallis Testi kullanılmıştır. Yapılan sinamada Asymp. Sig. değeri tüm alt boyutlar için 0,05’ten büyük olduğundan $H_{0}$ reddedilemez, eğitim durumuna göre sağlıklı yaşam merkezi üyelerinin sağlıklı yaşam merkezlerinden beklentilerinde istatistiksel olarak anlamlı bir fark yoktur sonucuna varılmaktadır. 
Tablo 8. Yaşa Göre Algı Ölçeği Fark Analizi

\begin{tabular}{lllllll} 
& Personel Algis1 & $\begin{array}{l}\text { Program } \\
\text { Alg1S1 }\end{array}$ & $\begin{array}{l}\text { Soyunma } \\
\text { Odas1 Algis1 } 1\end{array}$ & $\begin{array}{l}\text { Fiziksel } \\
\text { Özellikler } \\
\text { Alg1s1 }\end{array}$ & $\begin{array}{l}\text { Antrenman } \\
\text { Tesisi Alg1S1 }\end{array}$ & $\begin{array}{l}\text { Çocuk Bakımı } \\
\text { Alg1s1 }\end{array}$ \\
\hline Chi-square & 5,85 & 5,44 & 8,00 & 5,19 & 5,47 & 3,32 \\
Df & 4 & 4 & 4 & 4 & 4 & 4 \\
Asymp. Sig. &, 210 &, 245 &, 091 &, 268 &, 242 &, 506 \\
\hline
\end{tabular}

a. Kruskal Wallis Testi

$H_{0}$ : Yaşa göre sağlıklı yaşam merkezi üyelerinin sağlıklı yaşam merkezi algılarında istatistiksel olarak anlamlı bir fark yoktur.

$H_{A}$ : Yaşa göre sağlıklı yaşam merkezi üyelerinin sağlıklı yaşam merkezi algılarında istatistiksel olarak anlamlı bir fark vardır

Normallik testi bulgusu doğrultusunda parametrik olmayan Kruskal Wallis Testi kullanılmıştır. Yapılan sinamada Asymp. Sig. değeri tüm alt boyutlar için 0,05’ten büyük olduğundan $H_{0}$ reddedilemez, yaşa göre göre sağlıklı yaşam merkezi üyelerinin sağlıklı yaşam merkezi algılarında istatistiksel olarak anlamlı bir fark yoktur sonucuna varılmaktadır.

Tablo 9. Cinsiyete Göre Beklenti Ölçeği Fark Analizi

\begin{tabular}{lllllll} 
& $\begin{array}{l}\text { Personel } \\
\text { Algisı }\end{array}$ & $\begin{array}{l}\text { Program } \\
\text { Algis1 }\end{array}$ & $\begin{array}{l}\text { Soyunma } \\
\text { Odası Algisı }\end{array}$ & $\begin{array}{l}\text { Fiziksel } \\
\text { Özellikler } \\
\text { Algis1 }\end{array}$ & $\begin{array}{l}\text { Antrenman } \\
\text { Tesisi Algis1 }\end{array}$ & $\begin{array}{l}\text { Çocuk Bakımı } \\
\text { Algısı }\end{array}$ \\
\hline Mann-Whitney U & 10668,50 & 11366,50 & 11376,00 & 11290,50 & 10896,50 & 11034,50 \\
Wilcoxon W & 20964,50 & 21662,50 & 21672,00 & 21586,50 & 21192,50 & 21330,50 \\
Z & $-1,585$ &,- 664 &,- 658 &,- 767 & $-1,291$ & $-1,119$ \\
Asymp. Sig. (2-tailed) &, 113 &, 507 &, 510 &, 443 &, 197 &, 263 \\
\hline
\end{tabular}

$H_{0}$ : Cinsiyete göre sağlıklı yaşam merkezi üyelerinin sağlıklı yaşam merkezi beklentilerine istatistiksel olarak anlamlı bir fark yoktur.

$H_{A}$ : Cinsiyete göre sağlıklı yaşam merkezi üyelerinin sağlıklı yaşam merkezlerinden beklentilerinde istatistiksel olarak anlamlı bir fark vardır.

Normallik testi bulgusu doğrultusunda parametrik olmayan Mann Whitney U Testi kullanılmıstır. Yapılan sinamada Asymp. Sig. değeri tüm alt boyutlar için 0,05’ten büyük olduğundan $H_{0}$ reddedilemez, cinsiyete göre sağlıklı yaşam merkezi üyelerinin sağlıklı yaşam merkezi algılarında istatistiksel olarak anlamlı bir fark yoktur sonucuna varılmaktadır. 
Tablo 10. Medeni Duruma Göre Beklenti Ölçeği Fark Analizi

\begin{tabular}{lllllll} 
& $\begin{array}{l}\text { Personel } \\
\text { Alg1s1 }\end{array}$ & $\begin{array}{l}\text { Program } \\
\text { Alg1s1 }\end{array}$ & $\begin{array}{l}\text { Soyunma } \\
\text { Odas1 Alg1s1 }\end{array}$ & $\begin{array}{l}\text { Fiziksel } \\
\text { Özellikler } \\
\text { Alg1s1 }\end{array}$ & $\begin{array}{l}\text { Antrenman } \\
\text { Tesisi Alg1s1 }\end{array}$ & $\begin{array}{l}\text { Çocuk Bakımı } \\
\text { Algis1 }\end{array}$ \\
\hline Mann-Whitney U & 10509,50 & 10438,00 & 10262,00 & 10524,50 & 11339,00 & 10990,50 \\
Wilcoxon W & 17769,50 & 17698,00 & 17522,00 & 17784,50 & 29294,00 & 18250,50 \\
Z & $-1,122$ & $-1,219$ & $-1,473$ & $-1,107$ &,- 001 &,- 480 \\
Asymp. Sig. (2-tailed) &, 262 &, 223 &, 141 &, 268 &, 999 &, 632 \\
\hline
\end{tabular}

$H_{0}$ : Medeni duruma göre sağlıklı yaşam merkezi üyelerinin sağlıklı yaşam merkezi algılarında istatistiksel olarak anlamlı bir fark yoktur.

$H_{A}$ : Medeni duruma göre sağlıklı yaşam merkezi üyelerinin sağlıklı yaşam merkezi algılarında istatistiksel olarak anlamlı bir fark vardır.

Normallik testi bulgusu doğrultusunda parametrik olmayan Mann Whitney U Testi kullanılmıştır. Yapılan sinamada Asymp. Sig. değeri tüm alt boyutlar için 0,05’ten büyük olduğundan $H_{0}$ reddedilemez, medeni duruma göre sağlıklı yaşam merkezi üyelerinin sağlıklı yaşam merkezi algılarında istatistiksel olarak anlamlı bir fark yoktur sonucuna varılmaktadır.

Tablo 11. Eğitim Durumuna Göre Beklenti Ölçeği Fark Analizi

\begin{tabular}{lllllll} 
& Personel Alg1S1 & Program Alg1S1 & $\begin{array}{l}\text { Soyunma } \\
\text { Odas1 Alg1S1 }\end{array}$ & $\begin{array}{l}\text { Fiziksel } \\
\text { Özellikler } \\
\text { Alg1s1 }\end{array}$ & $\begin{array}{l}\text { Antrenman } \\
\text { Tesisi Alg1S1 }\end{array}$ & $\begin{array}{l}\text { Çocuk Bakım1 } \\
\text { Alg1s1 }\end{array}$ \\
\hline Chi-square & 3,028 & 5,673 & 5,063 & 3,918 & 4,073 & 4,082 \\
Df & 4 & 4 & 4 & 4 & 4 & 4 \\
Asymp. Sig. &, 553 &, 225 &, 281 &, 417 &, 396 &, 395 \\
\hline
\end{tabular}

$H_{0}$ : Eğitim durumuna göre sağlıklı yaşam merkezi üyelerinin sağlıklı yaşam merkezi algılarında istatistiksel olarak anlamlı bir fark yoktur.

$H_{A}$ : Eğitim durumuna göre sağlıklı yaşam merkezi üyelerinin sağlıklı yaşam merkezi algılarında istatistiksel olarak anlamlı bir fark vardır.

Normallik testi bulgusu doğrultusunda parametrik olmayan Kruskal Wallis Testi kullanılmıştır. Yapılan sinamada Asymp. Sig. değeri tüm alt boyutlar için 0,05’ten büyük olduğundan $H_{0}$ reddedilemez, eğitim durumuna göre sağlıklı yaşam merkezi üyelerinin sağlıklı yaşam merkezi algılarında istatistiksel olarak anlamlı bir fark yoktur sonucuna varılmaktadır. 
Tablo 12. Alınan Hizmetten Memnuniyet Düzeyine Göre Üyelik Yenileme

\begin{tabular}{llll} 
& Aldığınız Hizmetten Memnun Musunuz? & N & Ortalama \\
\hline Tekrar Üye Olur Musunuz? & Hiç Memnun Değilim & 162 & 150,63 \\
& Memnun Değilim & 111 & 154,14 \\
& Kararsızım & 26 & 166,77 \\
& Memnunum & 5 & 204,80 \\
& Son Derece Memnunum & 5 & 204,80 \\
& Total & 309 & \\
\hline
\end{tabular}

Tekrar Üye Olur Musunuz?

Chi-square

df

Asymp. Sig.
18,408

4

, 001

a. Kruskal Wallis Testi

b. Grup Değişkeni: Aldığınız izmetten Memnun Musunuz?

$H_{0}$ : Alınan hizmetten memnuniyet düzeyine göre sağlıklı yaşam merkezi üyelerinin tekrar üyelik düşüncelerinde istatistiksel olarak anlamlı bir fark yoktur.

$H_{A}$ : Alınan hizmetten memnuniyet düzeyine göre sağlıklı yaşam merkezi üyelerinin tekrar üyelik düşüncelerinde istatistiksel olarak anlamlı bir fark vardır.

Normallik testi bulgusu doğrultusunda parametrik olmayan Kruskal Wallis Testi kullanılmıştır. Yapılan sınamada Asymp. Sig. değeri 0,05’ten küçük olduğundan $H_{0}$ RED, alınan hizmetten memnuniyet düzeyine göre sağlıklı yaşam merkezi üyelerinin tekrar üyelik düşüncelerinde istatistiksel olarak anlamlı bir fark vardır sonucuna varılmaktadır. Rank değerleri incelendiğinde aldıkları hizmetten memnun ve son derece memnun olan katılımcıların diğer katılımcılara göre üyelik yenileme konusunda daha olumlu oldukları görülmektedir.

Tablo 13. Ödenen Ücretten Memnuniyet Düzeyine Göre Üyelik Yenileme

\begin{tabular}{llll}
\hline Özellik & & $\mathrm{N}$ & Yüzde \\
\hline Bu tesisten aldığınız hizmete göre ücreti nasıl & Oldukça yüksek & 53 & 17,1 \\
değerlendiriyor sunuz? & Kismen Yüksek & 73 & 23.6 \\
& Normal & 93 & 30,0 \\
& Kismen Düşük & 52 & 16,8 \\
& Oldukça Düşük & 38 & 12,2 \\
& Toplam & 309 & 100,0 \\
\hline
\end{tabular}

Tekrar Üye Olur Musunuz? 


\begin{tabular}{ll}
\hline Chi-square & 3,457 \\
df & 2 \\
Asymp. Sig. &, 178 \\
\hline
\end{tabular}

a. Kruskal Wallis Testi

b. Gruplandırma Değişkeni: Alınan Hizmete Göre Ödenen Ücretten Memnun Musunuz?

$H_{0}$ : Ödenen ücretten memnuniyet düzeyine göre sağlıklı yaşam merkezi üyelerinin tekrar üyelik düşüncelerinde istatistiksel olarak anlamlı bir fark yoktur.

$H_{A}$ : Ödenen ücretten memnuniyet düzeyine göre sağlıklı yaşam merkezi üyelerinin tekrar üyelik düşüncelerinde istatistiksel olarak anlamlı bir fark vardır.

Normallik testi bulgusu doğrultusunda parametrik olmayan Kruskal Wallis Testi kullanılmıştır. Yapılan sinamada Asymp. Sig. değeri 0,05’ten büyük olduğundan $H_{0}$ RED, ödenen ücretten memnuniyet düzeyine göre sağlıklı yaşam merkezi üyelerinin tekrar üyelik düşüncelerinde istatistiksel olarak anlamlı bir fark yoktur sonucuna varılmaktadır.

\section{TARTIŞMA VE SONUÇ}

Daha önce Sağlıklı yaşam merkezlerindeki hizmet kalitesi ölçümü ile ilgili birçok çalışma yapılmıştır. Yaşar’ın (2013) yaptığı araştırmada, hizmet kalitesinin alt boyutlarından alet ve ekipmanların ve soyunma odalarının kalitesinin hizmet kalitesini en çok etkileyen faktörler olduğu, yaş ve kulübe üye olunan süre arttıkça hizmet kalitesinden memnuniyetin azaldığı görülmüştür.

Savaş (2012) hizmet kalitesinin, müşteri tatmini ve müşteri sadakati ile anlamlı ve pozitif bir ilişki içerisinde olduğunu ortaya koymuştur. Konuya ilişkin benzer çalışmalar arasından Eroğlu tarafından (2006) araştırma yapılan tesislerde ve genel olarak diğer spor merkezlerinde üyelik yenileme oranlarının\% 20 - 25 olduğu görülmektedir. Üyelik yenilemelerin genellikle tesisi uzun süre kullanan ve düzenli spor yapan kişilerden oluştuğunu görmekteyiz. Spor merkezine düzenli olarak gelen bireyler ile düzensiz olarak gelen bireylerin spor yapma sıklıklarında ve üyelik yenilemelerini etkileyen faktörler arasında farklılıklar tespit edilmiştir. Spor merkezini kullanan bireylerin spor yapma süreleri arttıkça daha düzenli spor yaptıkları görülmüştür. Spor merkezini akşamüstü kullanan bireyler, spor merkezini diğer zamanlarda kullanan bireylere göre hizmet kalitesini daha düşük almaktadırlar. Spor merkezinde düzenli ya da düzensiz spor yapan bireylerin yaş, cinsiyet, medeni durum, eğitim seviyeleri gibi demografik faktörlerde farklılıklar tespit edilmiştir. Bu çalışma kapsamında yaşa göre merkezlere yönelik beklentide farklılık tespit edilmiştir ki yaşın etkileri göz önüne alınarak bu anlamda benzer sonuçlar elde edildiğinden söz etmek mümkündür.

Konuya ilişkin son zamanlarda yapılmış olan bir diğer çalışma ise Değer'in (2018) Ankaradaki Beş Yıldızlı Otellerde Bir Uygulama adlı çalışmasıdır. Bu çalışmanın gerçekleştirilen çalışma ile hizmet kalitesi yönü ile benzer olduğu görülmektedir. Araştırma verilerine göre Spa ziyaretçilerinin hizmet kalitesi beklentilerinin yüksek olduğu ancak alınan hizmet sonrası algının daha düşük 
olduğu belirlenmiştir. Dolayısıyla katılımcıların Spa işletmelerinden beklentilerinin tam olarak karşılanamadığı görülmüştür. Bununla birlikte araştırma sonuçlarına göre hizmet kalitesi ve gösterişçi tüketim eğilimleri arasında anlamlı ve negatif yönlü bir ilişki olduğu anlaşılmıştır. Ayrıca yapılan farklılık testi sonuçlarına göre ziyaretçilerin hizmet kalitesinin karşılanma düzeyi eğitim durumuna göre farklılık göstermezken, medeni duruma ve milliyete göre farklılık gösterdiği ve aynı zamanda cinsiyete, yaşa ve gelir durumuna göre de kısmen farklılıkların olduğu tespit edilmiştir. Yapılan analizler neticesinde yaşa ve alınan hizmete göre farklılıklar tespit edilmiştir ki Mehmet Değer’e ait veriler ile bu yönden benzer sonuçlar elde edildiği görülmektedir. Çalışmada üyelik yenileme eğilimi araştırılmamıştır.

Sağlıklı yaşam merkezlerindeki hizmet kalitesi ve kullanıcı beklentilerine yönelik çalışmalar henüz ülkemizde yeterli düzeyde olmasa da bu alana yönelik araştırmaların arttı̆̆ı görülmektedir. $\mathrm{Bu}$ araştırmalarda elde edilen bulgular sağlıklı yaşam merkezi yöneticilerine önemli bilgiler sunmaktadır. Son yıllarda artan talep ve beraberinde arz ile birlikte sektörel bazda rekabet artmış durumdadır. Bu rekabet koşulları içerisinde farklılık yaratmak ve ön plana çıkmak ise şüphesiz tüketici memnuniyetini sağlamak, tüketici sadakati oluşturmak ile mümkündür. Ülkemizin sahip olduğu jeopolitik konum ile birlikte SPA turizmi adına önemli bir potansiyele sahip olunması sektöre yönelik yatırımları arttırdığı gibi sağlıklı yaşam merkezlerinin hizmet hassasiyetini de arttırmaktadır. Tüm bu gerçeklerden yola çıkarak araştırma kapsamında elde edilen bulgular sağlıklı yaşam merkezi yönetimlerine önemli bilgiler sunmaktadır. Araştırma kapsamında yaşa göre bireylerin hizmet kalitesi beklentilerinin farklılık gösterdiği görülmektedir. 18 yaş altı ve 50 yaş üstü bireylerin beklentileri diğer bireylere göre daha düşüktür. Bununla birlikte alınan hizmetten memnuniyet düzeyine göre bireylerin üyeliklerini yenileme isteklerinde de farklılık tespit edilmiştir. Beklenildiği üzere hizmet kalitesi bireylerin sağlıklı yaşam merkezine yönelik görüşlerini doğrudan etkilemektedir ve bu da üyelik yenileme yaklaşımlarında belirgin bir farklılığa yol açmaktadır. Sağlıklı yaşam merkezlerinin öncelikli olarak kullanıcıları tatmin edici bir hizmet kalitesine ulaşmaları büyük önem taşımaktadır. Ödenen ücretten memnuniyet düzeyine göre sağlıklı yaşam merkezi üyelerinin tekrar üyelik düşüncelerinde istatistiksel olarak anlamlı bir fark yoktur. Netice itibari ile üyelik yenilemede etken olan parametrenin memnuniyet olduğu, fiyat olmadığı sonucuna varılmıştır. Yapılan araştırmalardan çıkan dolaylı sonuçlar ise sektördeki tüketicilerin beklentilerinde farklılıklar olduğu, esasında tüketicilerin beklentilerinde çok da bilinçli olmadığı yönündedir. Burada, işletme sahipleri ve yöneticileri için önemle vurgulanması gereken nokta; üyelik yenileme davranışının işletmelerin sunduğunu düşündüğünü hizmet standartları ile değil üyelerin algıladıkları standartlarla, nihai olarak üyelerin göreceli memnuniyetleri ile doğru orantılı olduğudur. Sübjektif olan kişisel memnuniyeti sağlamak için ise standart hale getirilmiş kişiye özel yaklaşımlar önerilmektedir.

\section{ÖNERILER}

Araştırma bulguları kapsamında getirilebilecek öneriler şunlardır:

- Sağlıklı yaşam merkezleri, yaş aralıklarına göre hizmet farklılıkları oluşturmalıdır. 
- Hizmet kalitesi ekonomik başarıyı direkt olarak etkilemektedir. Hizmet kalitesini artırmak adına Toplam Kalite Yönetimi benzeri yaklaşımlar tercih edilmelidir.

- Hizmet kalitesine ulaşmak için operasyonun mükemmelliği kadar iletişim ve algı da önemlidir. İletişime, süreçlere ve özellikle ilişkisel pazarlamaya gereken önem verilmelidir.

- Türkiye standartlarında bireylerin iş hayatında etkin bir şekilde yer aldıkları yaş aralığı olan 1840 yaş aralı̆̆ındaki bireyler doğrudan hedef kitle olarak baz alınarak bu kitlenin beklentilerini karşılayacak hizmet kalitesine ulaşmak da sağlıklı yaşam merkezlerinin benimsemesi gereken pazarlama ve hizmet stratejisi olarak ön plana çıkmaktadır.

- Sağlıklı yaşam merkezlerinin öncelikli olarak kullanıcıları tatmin edici bir hizmet kalitesine ulaşmaları büyük önem taşımaktadır.

- Üyelik sistemi ile çalışan sağlıklı yaşam merkezleri hem fiyatta hem de hizmette istikrar sağlamalıdır.

- İleriki araştırmalarda farklı fiyat uygulamaları ile ilgili algıyı ölçen sorular eklenebilir.

- Toplam Kalite Yönetimi uygulayan işletmeler ile Toplam Kalite Yönetimi uygulamayan işletmelerin üyelik yenileme mukayesesi başka bir çalışmanın konusu olarak değerlendirilmelidir.

\section{KAYNAKLAR}

Biçer, T. (2008). Sporda Toplam Kalite Yönetimi ve Futbol Uygulamaları, Beyaz Yayınları.

Çankaya F, Çilingir Z. (2008). Hizmet Sadakatinin Geliştirilmesinde Bir Fayda Maliyet Yaklaşımı: Bankacılık Sektöründe Bir Uygulama, Anadolu Üniversitesi Sosyal Bilimler Dergisi, Cilt/Vol::8 - Sayı/No: 1 : $25-$ 46.

Değer, M. (2018). Rekreaktif etkinlik açısından sağlıklı yaşam merkezlerindeki (SPA) hizmet kalitesinin belirlenmesi: Ankara’daki beş yıldızlı otellerde bir uygulama. Doktora Tezi, Gazi Üniversitesi, Ankara.

Eroğlu, E. (2006). Spor merkezlerinde üyelik yenilemelerini etkileyen faktörlerin araştırılması, Yüksek Lisans Tezi, Marmara Üniversitesi, İstanbul.

Ferrand A, Robinson L, Florence PV. (2010). The Intention-to-Repurchase Paradox: A Case of the Health and Fitness Industry, Journal of Sport Management, 24, s. 83-105.

Ganesh J, Arnold MJ, Reynolds KE. (2000). Understanding the Customer Base of Service Providers: An Examination of the Differences Between Switchers and Stayers, Journal of Marketing, Vol 64, 65-87.

Güdül, N. (2008). Fitness Salonlarına Giden Bireylerin Beklentileri, Yüksek Lisans Tezi, Afyon Kocatepe Üniversitesi, Afyon.

Gülbuçuk, A. (2008). Müşteri Bağlılığı Yaratmada Fiyat Politikasının Önemi ve Uygulanan Fiyatlandırma Yöntemlerinin Değerlendirilmesi, Yönetim ve Ekonomi Dergisi, Cilt:15 Sayı:1 Celal Bayar Üniversitesi İİBF.

Gürbüz, B., Koçak, S. ve Lam, E. T. C. (2005). Hizmet Kalitesi Değerlendirme Ölçeği’ nin Türkçe versiyonunun güvenirliği ve geçerliği. Eğitim ve Bilim, 31(13), 70-77.

Howat G, Absher J, Crilley G, Milne I (1996). Measuringcustomer service quality in sports and leisure centers. Manage. Leisure, 1: 77 - 89. 
Lam, E.T.C., Zhang, J.J. ve Jensen, B.E. (2005). Service quality assessment scale (SQAS): an instrument for evaluating service quality of health-fitness clubs. Measurement in Physical Education And Exercise Science, 9(2), 79-111.

Parasuraman A, Zeithaml VA, Berry LL. (1985). A Conceptual Model of Service Quality and Ist Implications for Future Research, Journal of Marketing, Vol 49, 41-50.

Raza A, Rehman Z. (2012). Impact of Relationship Marketing Tactics on Relationship Quality and Customer Loyalty: A Case Study of Telecom Sector of Pakistan, African Journal of Business Management Vol. 6(14), pp. 5085-5092.

Savaş, N. (2012). Hizmet kalitesi, müşteri tatmini ve müşteri sadakati: Fitness merkezi üyeleri üzerinde bir inceleme. Yüksek Lisans Tezi, Balıkesir Üniversitesi, Balıkesir.

Turizm Tesislerinin Belgelendirilmesine ve Niteliklerine İlişkin Yönetmelik, T.C. Resmi Gazete 21 Haziran 2005, say1: 8948, http://www.mevzuat.gov.tr/MevzuatMetin/3.5.20058948.pdf, erişim 10 Ocak 2018.

Yazıcıŏ̆lu, Y. ve Erdoğan, S. (2004). Spss uygulamalı bilimsel araştırma yöntemleri. Ankara: Detay Yayıncılık.

Ylldız, SM. (2011). An Importance-Performance Analysis of Fitness Center Service Quality: Empirical Results From Fitness Centers in Turkey, African Journal of Business Management Vol. 5(16), pp. 7031-7041. 